\title{
Correction to: Uncertainty and Resolution Analysis of 2D and 3D Inversion Models Computed from Geophysical Electromagnetic Data
}

\section{Zhengyong $\operatorname{Ren}^{1}$ (D) . Thomas Kalscheuer ${ }^{2}$ (D)}

Published online: 2 December 2019

(C) The Author(s) 2019

\section{Correction to: Surveys in Geophysics https://doi.org/10.1007/s10712-019-09567-3}

An error has been found and should be corrected.

On page 37 of this paper published online, immediately above Fig. 8, the phrase "Heincke et al. (2017) developed an adaptive strategy to determine the weights for different data misfit terms in 1D joint inversion" should be replaced by the phrase "Heincke et al. (2017) developed an adaptive strategy to determine the weights for different data misfit terms in 2D joint inversion”.

Acknowledgements We thank Björn H. Heincke for pointing out this error.

Open Access This article is distributed under the terms of the Creative Commons Attribution 4.0 International License (http://creativecommons.org/licenses/by/4.0/), which permits unrestricted use, distribution, and reproduction in any medium, provided you give appropriate credit to the original author(s) and the source, provide a link to the Creative Commons license, and indicate if changes were made.

\section{Reference}

Heincke B, Jegen M, Moorkamp M, Hobbs RW, Chen J (2017) An adaptive coupling strategy for joint inversions that use petrophysical information as constraints. J Appl Geophys 136:279-297. https://doi. org/10.1016/j.jappgeo.2016.10.028

Publisher's Note Springer Nature remains neutral with regard to jurisdictional claims in published maps and institutional affiliations.

The original article can be found online at https://doi.org/10.1007/s10712-019-09567-3.

Thomas Kalscheuer

thomas.kalscheuer@geo.uu.se

Zhengyong Ren

renzhengyong@csu.edu.cn

1 School of Geosciences and Info-Physics, Central South University, Changsha 410083, China

2 Department of Earth Sciences, Uppsala University, 75236 Uppsala, Sweden 